Political and Judicial Checks on Corruption

Evidence from American State Governments

Alt, James E.; Lassen, David Dreyer

Publication date:

2005

Document version

Publisher's PDF, also known as Version of record

Citation for published version (APA):

Alt, J. E., \& Lassen, D. D. (2005). Political and Judicial Checks on Corruption: Evidence from American State Governments. Economic Policy Research Unit. Department of Economics, University of Copenhagen. http://econpapers.repec.org/paper/kudepruwp/05-12.htm 


\section{EPRU Working Paper Series}

Economic Policy Research Unit

Department of Economics

University of Copenhagen

Studiestræde 6

DK-1455 Copenhagen K

DENMARK

Tel: (+45) 35324411

Fax: (+45) 35324444

Web: http://www.econ.ku.dk/epru/

Political and Judicial Checks on Corruption:

Evidence from American State Governments

James E. Alt

David Dreyer Lassen

2005-12

ISSN 0908-7745

The activities of EPRU are financed by a grant from The National Research Foundation 


\title{
Political and Judicial Checks on Corruption: Evidence from American State Governments*
}

\author{
James E. Alt \\ Department of Government \\ Harvard University \\ and \\ David Dreyer Lassen ${ }^{\S}$ \\ Economic Policy Research Unit \\ and \\ Department of Economics \\ University of Copenhagen
}

August 2005

\begin{abstract}
The paper investigates the effects of checks and balances on corruption. Within a presidential system, effective separation of powers is achieved under divided government, with the executive and legislative branches being controlled by different political parties. When government is unified, no effective separation exists even within a presidential system, but, we argue, can be partially restored by having an accountable judiciary. Our empirical findings show that divided government and elected, rather than appointed, state supreme court judges are associated with lower corruption and, furthermore, that the effect of an accountable judiciary is stronger under unified government, where government cannot control itself. The effect of an accountable judiciary seems to be driven primarily by judges chosen through direct elections, rather than those exposed to a retention vote following appointment.
\end{abstract}

Keywords: separation of powers, corruption, rent seeking, checks and balances, political institutions, judicial independence, rule of law

JEL-codes: D72, D73, P48

\footnotetext{
* We thank participants at the Annual Meeting of the American Political Science Association, Chicago, September 2004, for comments and suggestions, Phil Keefer for comments on an early presentation of the main argument, and Tim Besley, Carles Boix and Laura Langer for sharing their data.

§ Corresponding author: david.dreyer.lassen@econ.ku.dk
} 


\section{$\underline{\text { I. Introduction }}$}

The principle of separation of powers, where the legislative, executive and judicial functions of government are divided among separate and independent bodies, is a cornerstone of governance in democratic nations. Separation of powers implies the need for multiple actors to propose, initiate, or manage the agenda, and is, in constitutional design, considered a necessary bulwark against tyranny. In itself, however, a system of separation of powers does not prevent the misuse of power. This requires procedures which enable actors to stop or block the actions of other actors. Such procedures, known as checks and balances, empower the separate actors to prevent actions by other actors, for example through vetoes, judicial review or regulatory oversight, with the aim of ensuring policy moderation and preventing misuse of political power.

In spite of significant investments in institutional design, however, abuse of political power at the expense of citizens remains an endemic problem in developing countries, and a persistent one even in developed democracies. Such abuse can take many forms, and is not always simple to define, covering the spectrum from enacting legislation for the benefit of smaller groups of supporters or voters to receiving direct payments for political favours. In recent years, both academics and practitioners have put a lot of focus on such corruption, commonly defined as the misuse of public office for private gain. It is a popular belief that separation of powers in combination with various forms of checks and balances constitute a crucial safeguard against corruption of government. However, this fundamental assertion has proved difficult to verify empirically, partly due to missing counterfactuals, as no democratic countries completely without separation of powers exist, and partly due to problems of defining an operational measure of checks and balances for a cross-country setting.

In this paper, we combine recent work in political agency (Persson, Roland and Tabellini, 1997) with survey data on corruption in American states to conduct an empirical 
investigation of the relationship between corruption and checks and balances in political institutions. We use the presence of divided government as an operational measure of checks and balances in combination with data on judicial selection to explain the prevalence of corruption in American state governments.

Most empirical research on the determinants of corruption has been conducted in cross-national contexts (Ades and di Tella, 1999; Treisman, 2000; Montinola and Jackman, 2002), focusing on historical, economic and cultural determinants of corruption. Within this comparative literature, recent work has concentrated on empirical investigations of how political institutions shape the incentives for politicians to engage in illegal rent-seeking and corrupt activities. Persson, Tabellini and Trebbi (2003) examine how electoral rules such as district magnitude, the ballot structure and the electoral formula (proportional vs. majoritarian) affect corruption. Kunicová and Rose-Ackerman (2004) look in more detail on closed vs. open list voting under proportional rule, and on presidential vs. parliamentary regimes. Gerring and Thacker (2004) consider the interaction between constitutional structure and unitary vs. federal regimes. The general conclusion is that political institutions matter for corruption, in ways predicted by the theoretical models of rentseeking by elected officials.

Many of the conclusions of the comparative work have been confirmed, and, indeed, derived independently, in work on corruption in American state governments. Most of the literature on the states, beginning with Meier and Holbrook (1992), has used hard data on federal prosecutions and convictions related to corruption; see also Adserà et al. (2003), Glaeser and Saks (2004) and Maxwell and Winters (2005). One consistent finding is that corruption appears to be lower in states with a better educated citizenry, and additional findings include the dampening effects of newspaper circulation (Adserà et al.) and the increasing effect on corruption of the number of governments (Maxwell and Winters). Alt and Lassen (2003), on the contrary, use survey 
data from Boylan and Long (2003) to investigate the effect of political institutions, including the possibility of popular initiatives, restrictions on campaign finance, and the openness of party primaries on corruption, all of which are found to decrease corruption.

The general impression left by the literature is that political institutions do matter for the prevalence of corruption. The idea that checks and balances reduce corruption is certainly prevalent: Glaeser and Goldin (2004, p. 19) note that

"[b]y the twentieth century, the full apparatus of modern checks on corruption were in place. Rules had generally replaced discretion in many areas such as patronage. Different levels of government more effectively patrolled each other.”

Wallis (2004) provides a historical account of the evolution of ideas that led to this modern system of checks and balances. However, as noted above, no systematic work exists on the effects of a system of checks and balances, including both divided government and the role of the judiciary. That is our task. ${ }^{1}$

Regarding the judiciary, work in political science and economics has recently begun looking in more detail at the causes and consequences of legal institutions, in large part due to a large body of work successfully relating institutional differences and differential economic outcomes to variations in legal systems or families. Glaeser and Shleifer (2002) provide an introduction to this literature. Judicial independence, argued to be of central importance for the judiciary’s role as watchdog of the other branches of governments by Hayek and others, has been investigated by La Porta et al. (2004) and Feld and Voigt (2003).

Related to this interest is work on the effects of judicial independence and selection on outcomes in American states. As for the case of divided government, the basic legal institutional varieties in the states have been well-established for a long period of time. Recent work uses both

\footnotetext{
${ }^{1}$ Di Tella and Fisman (2002) consider the determinants of gubernatorial pay in American states. They find that the income elasticity of gubernatorial pay is smaller under divided government and, thus, their paper is complementary to parts of this paper in that they consider legal rent-seeking, i.e. rent seeking within the limits of the law, while we look at the effects of divided government on illegal rents.
} 
within-state and cross-state variations in state supreme court selection procedures to identify the consequences of such procedures, mostly for public policy. For example, Besley and Payne (2003) consider the effects of judicial selection procedures on employment discrimination charges while Langer (2002) considers how selection procedures, and other factors, affect a wide range of policy areas including workers compensation law, campaign and election laws, and unemployment compensation laws. Below, we apply the logic of this literature to corruption.

In the next section, we briefly review the approach of Persson, Roland and Tabellini (1997), and develop the arguments to be investigated empirically. Section three describes the data and empirical strategy, section four reports results, and section five discusses robustness and causality issues. Section six concludes.

\section{Political Agency, Judicial Selection and Corruption}

Barro (1973) and Ferejohn (1986) model the relationship between voters and politicians in a democracy as a principal-agent problem. Voters, the principals, choose a politician, the agent, who in turn rules the voters. The basic premise for this view of the political process is that voters' interests and politicians' (private) goals are not perfectly aligned, so that the authority bestowed upon politicians creates scope for actions that voters dislike. ${ }^{2}$ In a reformulation of the Ferejohnmodel, Persson, Roland, and Tabellini (1997), henceforth denoted PRT, model this political agency problem as one of rent-extraction: Voters pay taxes in order to finance public goods provision with uncertain costs, and politicians, knowing these costs, can exploit the asymmetry of information in order to reap rents for personal benefit.

The main contribution of PRT is to examine and explain the fundamental institution of separation of powers as a solution to such a political agency problem (see also Salzberger, 1993). In

\footnotetext{
${ }^{2}$ Besley (2003) provides a recent, comprehensive account of this approach.
} 
their model, direct elections (accountability) to two separate powers, the legislature and the executive, in a presidential system, combined with opposing interests allows the two powers to act as checks on each other, resulting in a reduction, and sometimes even elimination, of the informational asymmetries between voters and politicians. ${ }^{3}$ In this model, increasing accountability is always preferable from the viewpoint of the voters, as it decreases rents and, hence, increases public goods provision for a given level of taxation.

In later work, Persson, Roland, and Tabellini (2000) and Persson and Tabellini (1999) elaborate on this framework to gain insights into institutional determinants of public finance characteristics such as the size of the public sector. In this paper we build on PRT, but we take a different direction from the above papers. We reinterpret their original model as one of divided government and introduce the third part of Montesquieu’s separation of powers, the judiciary. We take this revised model to the data.

In the original model of PRT, there are no parties. The executive and the legislature are assumed to have different interests and, from this, a comparison of presidential and parliamentary systems is made. However, in contemporary real-world democracies, political parties, understood as organizations of competing politicians with opposing political and electoral goals, are a feature of almost all of political life. In the context of PRT, if the president belongs to the party that also holds a legislative majority, it is not at all certain that their interests will be diametrically opposed, or even opposed at all (see also Morgenstern, 2004). Interpreted this way, the model generates the prediction that rents should be lower under divided government than under unified government within a presidential political system. This is our first testable hypothesis.

The original model of PRT corresponds to a Lockean view of the separation of powers, in which the judiciary has no role. We instead consider the model of separation of powers

\footnotetext{
${ }^{3}$ Laffont (2001) provides a detailed account of the use of principal-agent models in political oversight of agencies.
} 
envisaged by Montesquieu, adding the judiciary. The exact role of the judiciary as a check on the other branches of government depends on the nature of the political misuse of power. If the legislature and/or executive enact policies that conflict with the legal code or constitutions, judicial review provides a safeguard through the possibility of policy reversal. If the problem is straightforward corruption, courts can act by sanctioning or punishing corrupt individuals. To investigate the effect of courts on corruption, we utilize the fact that selection procedures for state supreme court judges vary across the US states. In some states, judges are appointed, while in others they are elected. We explain this in more detail when we describe the data below.

How does this difference in judicial selection procedures affect corruption? In the judicial selection literature, there is agreement that appointed judges generally can act more independently from the political process, while elections are inherently political. Elections may cause officials to pander to public opinion, which can be inferior in some cases, but at the same time provide incentives for officials by holding them accountable for their actions and the resulting outcomes (Maskin and Tirole, 2004; Schultz, 2005). But there is a cost to appointment as well, in particular when the policy space is multidimensional. As stressed by Besley and Coate (2003) in the context of electricity regulators, if the regulatory dimension is not the salient one in a gubernatorial election, incumbent politicians are effectively given free rein in appointing their favourite regulator, and are possibly influenced by interest groups and their campaign contributions. A similar logic applies to judicial selection (Besley and Payne, 2003). If the selection of the judiciary is not salient when voting for governor, the winner of the election can appoint or reappoint state supreme court judges who may differ in terms of preferences and judicial interpretation from the median voter's choice. Therefore, 'unbundling' the choice of executive and judiciary powers into separate elections can yield an outcome where judicial preferences are closer to the median voter's preferences over judicial interpretation and action. Since corruption comes at the expense of (almost) all voters, we 
expect that a judiciary accountable to voters should be more concerned about curbing corruption. This is our second testable hypothesis. We comment further on the possible effects of partisan courts below.

Finally, we consider the interaction between the different branches of government. If government is divided in that the executive and legislature are controlled by different parties,, it can, by the argument above, control itself, and the role of the judiciary should be less important. However, under unified government, when government does not control itself, the judiciary becomes important in reducing rent-seeking; this is the logic of Montesquieu. It follows that the effect of an accountable judiciary on corruption will be larger under unified government; or, put differently, that divided government and an accountable judiciary will be substitutes in curbing corruption. This is our third testable hypothesis.

To assess the effects of checks and balances on corruption, we use data from American state governments. American state governments provide a promising arena for our purposes. All fifty state governments, in addition to being embedded in a country with common heritage and political culture, share the same basic institutional design, including a governor, a bicameral state legislature (except Nebraska), and a state supreme court. At the same time, however, they retain large variations in political and judicial institutions through individual state constitutions. Of consequence is that about half the states use direct elections to choose supreme court justices, and nearly half provide a situation in which the partisan majority of the court is opposed to that of the executive. This gives good balance to our investigation of the effects of these factors. Finally, as noted above, Glaeser and Goldin (2004) show that institutional responses to the problem of corruption were basically settled already in the early twentieth century. This contributes to the causal explanation that we wish to highlight; we return to this issue below. In sum, we find 
that these characteristics make the US states a good laboratory for assessing the impact of institutions on the prevalence of corruption. ${ }^{4}$

\section{Data and Empirical implementation}

There is a long tradition in quantitative corruption research for using subjective assessments, or combinations of such assessment aggregated into an index, to measure corruption; Transparency International's widely used Corruption Perceptions Index is perhaps the best known example of such a measure. As our measure of corruption, we use a comparable survey on public corruption in American state governments, carried out by Boylan and Long (2003). In 1998-99 they surveyed “state house” news reporters on their perception of state government corruption. These reporters cover the daily activities of the executive agencies and legislature, and are likely to be wellinformed observers of politics at the state level. Respondents were asked to rate their state in terms of level of corruption of all government employees (including elected officials, political appointees, and civil servants) on a seven point scale, from least corrupt (1) to most corrupt (7). We use the average of reporters' ratings from each state as our dependent variable: this yields a corruption measure for 47 states with an average of 3.5 and a standard deviation of 1.2. ${ }^{5}$ The three least corrupt states (average rating $=1.5$ ) according to this measure are Colorado, North Dakota, and South Dakota, while the three most corrupt states (average rating $=5.5$ ) are Louisiana, New Mexico and Rhode Island.

Their survey is broadly in line with other measures of corruption for the US states, such as data on federal prosecution and conviction rates used by Meier and Holbrooke (1992), Adsera, Boix and Payne (2003), and Glaeser and Saks (2004). As argued by Boylan and Long, however, use of the convictions data in empirical analysis is problematic for several reasons. In

\footnotetext{
${ }^{4}$ Besley and Case (2003) provide a detailed survey of how political institutions affect outcomes in American states.

${ }^{5}$ There were no or too few respondents in New Hampshire, New Jersey and Massachusetts.
} 
particular, they find that the number of federal convictions on corruption charges depends not only on the level of corruption in a given state, but also crucially on the priority and amount of effort prosecutors devote to cases involving public officials, which may vary by state for a number of reasons.

Our main explanatory variables involve institutional checks and balances: these include the presence of divided government, and the selection procedure and partisan orientation of the state supreme court. Divided government is measured, as are most independent variables, as a ten-year average over the period 1989-1998. Government is divided if different parties control the executive and the legislature (including the cases where the executive is independent). Neither we nor the literature takes a definitive stand on whether to code an executive facing a split legislature, where different parties control the two chambers, as unified or divided government, but we show throughout that this choice does not significantly affect our results. Sources for all the data are provided in the appendix.

Judicial selection for state supreme courts takes place in a variety of ways across the fifty states. While all judges for the federal level are appointed for life, judges at the state level can be elected in non-partisan or partisan elections, appointed, typically for a limited period, by the executive and/or the legislature, or selected through various combinations of appointment and elections. The combinations typically fall under the heading of merit or hybrid plans that combine initial appointment, typically by the governor in consultation with a nominating committee, with a subsequent popular retention vote. ${ }^{6}$

As we noted above, the choice of selection procedure continues to be a subject of great controversy among both scholars and practitioners; see Hall (2001) for an introduction to this discussion. In our sample we distinguish judges running in partisan or non-partisan elections from

\footnotetext{
${ }^{6}$ The merit or hybrid plan is sometimes known as the Missouri plan, as the procedure was first introduced in that state, in 1940. We follow Besley and Payne (2003) in using the term hybrid plan.
} 
those being appointed. Therefore, we initially code judges selected under the hybrid plan as appointed, but return to the implications of this below, as the exact coding of the merit plan judges allows us to gain some insights into the forces underlying the effects of the judiciary as a check on the other branches of government. ${ }^{7}$ In our 45 -state sample, we count 24 states that use a form of direct elections, 7 states that use an appointment scheme, and 14 that use the hybrid plan. This pattern did not change over the time period considered ${ }^{8}$ and the sample is thus almost evenly divided between states that use at least some elections and those that use only appointment.

Below, we further want to distinguish elected and appointed state supreme courts by their political orientation, in particular whether their partisanship places them in opposition to the other branches of government or not. Langer (2004) provides a database on the party affiliation and a constructed measure of political preferences (Brace et al. 2000) for each supreme court judge from 1960 onwards. For elected judges, partisan affiliation follows immediately, while for appointed judges she uses the party of the (majority of) the appointing body. ${ }^{9}$ As we are concerned mainly with partisan affiliation here, we do not explore the constructed ideology measures. For each state supreme court for each year from 1990 to 1999, we determine the partisan majority and continue to take the average over the decade. Based on this, we construct a binary variable for Democratic vs. Republican state supreme courts over the 1990s. To assess whether a state supreme court was in opposition, we need an operational measure of party control of the government. For unified governments, there is no question about which party controls state government, and the coding is straightforward. For divided governments we define a state supreme court to be in opposition if it is

\footnotetext{
${ }^{7}$ Besley and Payne compare selection effects and incentive effect of differing methods for choosing judges. Selection effects occur if the competence or underlying preferences of judges are a result of appointment vs. election, while incentive effects are a product of the method used for re-appointment/election. They find evidence for incentive effects, in line with the accountability effects identified by Hall (2001).

${ }^{8}$ This is not quite true: Rhode Island changed from appointment in the legislature to appointment by the Governor with a nominating commission without retention vote. This does not show up here, though. Tennessee changed from a partisan ballot to appointment with retention vote. This has no siginificant effect on the results.

${ }^{9}$ In the cases where judges run in non-partisan elections coding follows the procedure for appointed judges.
} 
majority-controlled by a party different from the current governor's. We count twenty states where the state supreme court on average was in opposition to the government as defined above.

In addition to these variables, and their interaction, we include controls for a wide range of variables generally found to influence corruption and government quality (Treisman, 2000; Alt and Lassen, 2003; Knack, 2002; Persson, Tabellini and Trebbi, 2003; Glaeser and Saks, 2004): Metropolitan population, per capita income, government size, education level (measured by share of population with high school diploma), and a social capital measure (share of population with Scandinavian ancestors). The latter was used as an instrument for social capital by Knack (2002) in his analysis of the quality of government in American state governments, partly due to the fact that the Scandinavian countries consistently have low levels of corruption in international comparison. In earlier work we found this variable to be significantly associated with lower corruption and, hence, include it here as a control. We comment on additional control variables below.

Our empirical specification is a standard OLS framework: We have only crosssectional data. We have no reason to believe that the relationship is not linear, nor a way of finding out given the data at hand. In the analysis, we account for heterogeneity in the errors by reporting robust standard errors. We also briefly consider IV-estimation to take into account possible reverse causation; more on this below.

\section{$\underline{\text { IV. Empirical results }}$}

Table 1 presents the results of the main specification, for both measures of divided government. The main explanatory variables are the share of the population residing in metropolitan areas, income per capita, share of the population with at least a high school diploma, state government tax revenue per capita, and share of population with Scandinavian ancestry. Throughout the analysis, these variables have the expected signs and are strongly significant. 
To this specification, based - as mentioned above - largely on cross-country work on the causes of corruption, we now add divided government (regressions (1) and (4)). States in which different parties control the executive and legislative branches have significantly lower corruption than states with unified government. The effect is slightly larger and somewhat more precisely estimated when a governor facing a split legislature is coded as divided government (regression (4), with the dependent variable denoted divgov). Our empirical estimates, hence, confirm the common intuition that divided government, or shared power, contributes to a system of checks and balances which prevents the abuse of power in public office. At the same time, then, it tentatively confirms our interpretation of the Persson, Roland and Tabellini model, that is, that parties have an important role in making the system of checks and balances work effectively. ${ }^{10}$

$$
<\text { Table } 1 \text { here }>
$$

We now add an indicator variable for elected state supreme court judges (regressions (2) and (5)), but find no direct effect of this variable. Do judicial selection procedures, then, not affect the degree of corruption? Indeed, they might not appear to, since we pointed out in the discussion above that having elected rather than appointed state supreme court judges could affect corruption both positively and negatively. On the other hand, remember that in our interpretation of the PRT model, the third branch of government becomes important exactly when government, understood as the legislature and the executive together, cannot control itself, which is the case under unified government. If that is the case, we need to augment the specifications in (2) and (5) with an interaction term to allow for the effect of the judiciary to be dependent on party control of government. This is done in specifications (3) and (6).

\footnotetext{
${ }^{10}$ We cannot add anything to the interpretation of PRT of their model in terms of differences in separation of powers between presidential and parliamentary systems. Since our sample includes only presidential regimes, it is possible that the hypothetical case of parliamentary state governments would prove more corrupt than unified presidential state governments. Kunicová and Rose-Ackerman (2004), though, finds presidential regimes to more corrupt than presidential ones on a comparative sample; see also Lassen (2005) who uses presidentialism as an instrument for corruption in an analysis of the size of the informal sector.
} 
Allowing for an interaction between divided partisan government and state supreme court selection procedures produces different results. While divided government continues to be significant, we also find that states that elect rather than appoint supreme court judges have lower corruption. Moreover, this effect of elected or accountable judges is particularly strong when government is unified, which is exactly when government cannot or does not always control itself. Thus, in this case the judiciary provides a check on the powers of the two other branches, as envisaged by Montesquieu. Conversely, the judicial selection procedures are of less importance in the Lockean case with divided government and thus no collusion among the branches, which is the case analysed by PRT. Again, the estimated checks and balances effects are largely the same across the two measures of divided government. ${ }^{11}$ From these basic results we now extend the analysis in several directions.

\section{Judicial selection and partisan conflict}

So far, we have analyzed the effects of elected vs. appointed state supreme courts as checks on corruption in the other branches of government in an "institutional" way, in the sense that we compare states using only the institutional selection procedure. We have not yet used information on political leanings or party affiliations of state supreme court judges. This is potentially important, as the same argument we made above for introducing parties into the PRT model of separation of powers supports adding parties to the institutional state supreme court argument. We believe the ability of courts to provide a check on other branches of government can be diminished if the courts have preferences for -- or even run on -- the platforms of particular parties. Indeed, the politicization of judicial selection that is often associated with partisan elections is put forward by the so-called

\footnotetext{
${ }^{11}$ We also considered the possibility that the effect of different partisan configurations of divided government could matter for the impact of divided government on corruption. To do this we included separately indicator variables for Democratic governor vs. Republican legislature and Republican governor vs. Democratic legislature. We cannot reject the null that the estimated coefficients are the same and, hence, continue to keep the non-partisan measure of divided government.
} 
“court reformers” as a main reason for switching to a hybrid plan (Hall, 2001). This line of argument echoes the early $20^{\text {th }}$ century Progressive movement, who argued for a switch from partisan to non-partisan judicial elections. Nevertheless, Hall (2001) and Hall and Bonneau (2003) show that party politics, measured by the degree of political competition, figures in all kinds of judicial elections, whether directly partisan, non-partisan, or retention elections following initial appointment in the hybrid plan.

To investigate whether the effectiveness of an elected court depends on partisan factors, we divide states with direct elections into those where the supreme court is in opposition to the other branches of government and those where this is not the case. We follow the definition provided in the data description above. Thus, we code a state as having "direct judicial elections in opposition" that, on average over the 1990s, had a majority of its elected supreme court with a partisan affiliation or proclivity different from that of the governor. Though the coefficients shift a little in offsetting ways, the overall estimated effects do not depend on whether divided legislatures are treated as unified or divided government. Results appear in Table 2.

$<$ Table 2 here $>$

Consider the results in the second column. Estimates for basic control variables and divided government are as before. Direct effects of elected, as opposed to appointed, state supreme courts on corruption come from states whose supreme courts are in partisan opposition to the government. The two estimates (across elected courts which are and are not in opposition) are marginally significantly different. Clearly, only elected courts in opposition significantly dampen corruption. Furthermore, the interaction effects - which are significantly different - suggest that the effect of an elected judiciary on corruption is strongest when it is in opposition to a unified government, confirming the institutional results achieved above in an intuitively expected direction. These results are unaffected by the inclusion of additional control variables. 
Selection vs. incentive effects

Hybrid selection schemes combine elements of appointment and elections. This allows us to investigate the relative importance of the selection process, which is carried out in the appointment procedure, and the effect of elections on accountability. Above, we coded hybrid selection procedures as appointment. If we change this coding to elections, emphasizing the retention vote rather than the appointment itself, we find that the effect of elected state Supreme Court justices or, rather, the precision with which the effect is estimated, does depend on the type of election (results not shown). If justices are directly elected, whether in partisan or non-partisan elections, they provide a check on executive powers, and this effect is significant as that found above. However, those justices that are first appointed but only later subject to a retention vote appear not to have a similar effect on corruption. This does not depend on whether we code supreme courts using only the institutional classification of Table 1 or the institutional-cum-partisan classification of Table 2.

This suggests that selection effects (cf. note 7) can be important when considering the state supreme court's role as a check on corruption in the other branches of government. Besley and Payne (2003) found that incentive, rather than selection, effects were the driving force in their results on worker discrimination cases. Hall (2001) found judges to be held accountable for murder rate increases across different types of elections. Our results suggest that the relative importance of selection and incentive effects can be different depending on the outcome under consideration.

\section{$\underline{\text { V. Robustness of empirical results }}$}

Table 3 introduces several sets of control variables. We pay particular attention to variables found significant in earlier work on corruption in US states (Alt and Lassen 2003). We check for other possible influences on corruption to minimize the possibility that the effects of checks and balances found above are due to spurious correlation, with divided government or judicial selection 
procedures capturing the effects on corruption of other variables. We present only the estimation results for the divgov variable, but these are indistinguishable from the results obtained using the dgov measure, where split legislatures are coded as unified government.

$$
<\text { Table } 3 \text { here }>
$$

The underlying conclusion that emerges from these robustness checks is that the effect of checks and balances on corruption is affected only slightly by the inclusion of additional control variables. In particular, divided government and the interaction term always remain significant, while the precision of the estimate of the direct effect of judicial selection procedures decreases slightly, in some cases becoming only borderline significant. The included control variables are also of interest in themselves. We find that corruption is significantly lower in Southern states. Campaign expenditure restrictions imply lower corruption, while we find less precisely estimated effects in these specifications of open vs. closed primaries (though this is significant when using the dgov measure), newspaper circulation, ${ }^{12}$ term limits and initiative provisions (which are borderline significant when using the dgov measure), and measures of political competition. We stress again that the estimated effects of most of the added explanatory variables remain in expected directions, but that their inclusion does not diminish the main effects estimated in this paper.

\section{Causality issues}

Our interpretation of the empirical results so far has been that there is a causal effect of the presence of divided government and judicial institutions on corruption. This is supported by the historical account of Wallis (2004) and Glaeser and Goldin (2004) that institutional response to the problem of corruption has been settled since the early twentieth century. Two potential problems exist, however, with this explanation. First, the observed correlation could be the result of reverse causality, that is, the causal effect may be that the presence of corruption in state governments

\footnotetext{
${ }^{12}$ Sometimes denoted the fourth branch of government, an independent media exposes corruption (Adserà et al. 2003). In principle, the effects could be contingent on the partisanship of the media, if these could be measured.
} 
induces voters to choose unified governments in order to lower corruption, or to push for judicial selection procedures different from direct partisan elections, rather than divided government and selection procedures being the causes of lower corruption.

A direct check of this reverse causality argument is to consider the effects of lagged corruption on divided government. Unfortunately, no survey similar to the one employed here exists for the 1980s, so we use the published figures on convictions for misuse of public office used by Meier and Holbrooke (1992). These were the first publicly available hard data on corruption for American state governments, and might well have influenced informed public perception of corruption at the state level. If we regress the presence of divided government in the 1990s on convictions data from the 1980’s we find no effects even close to significant, regardless of the measure for divided government, both in a univariate regression and controlling for all the other potential determinants of divided governments discussed above.

The second potential problem is that the demonstrated effects could simply be spurious correlation caused by omitted third factors like a "culture of corruption" which in turn is correlated with divided government and judicial selection procedures. When such omitted variables are not controlled, the variables of interest could be correlated with the error term of the regression leading to inconsistent empirical estimates. As the survey data is not available over time, we cannot employ panel data methods, such as fixed effects, to control for individual state effects not captured by the included control variables. ${ }^{13}$

Regarding a possible corruption culture (or lack thereof), we believe the inclusion of the (highly significant) share of the population reporting Scandinavian ancestors, while not perfect, goes some way towards capturing this (see Treisman, 2000, for comparative evidence that

\footnotetext{
${ }^{13}$ Even if we have had panel survey data, estimating the effects of judicial selection procedures would be difficult, as these have changed little during the last decade and the effects therefore would be difficult to identity due to correlation with state fixed effects. Other studies looking at judicial selection procedures (Hanssen, 2004; Besley and Payne, 2003) work with panels spanning back to 1950 and the 1970's, where much more frequent changes were taking place.
} 
Scandinavian countries have lower corruption, and Knack, 2002, for effects of Scandinavian ancestry on measures of social capital in the US). We also experimented with various state level measures of the strength of the Progressive movement of the early twentieth century, which had combating corruption as a central agenda. These measures were negatively related to corruption in the 1990's, but were generally insignificant and did not affect the estimates of the other variables' effects on corruption in any way. The wide range of potential controls considered above, and their small influence on the estimated effects for the variables of interest considered here, also provides some reassurance that spurious correlation is not the key reason for the observed results.

Finally, we also investigated the possibility of establishing causality with an instrumental variables method. If we could identify variables that affect the occurrence of divided government and at the same time do not affect corruption, this would provide a stronger case for a causal interpretation of the empirical findings. However, as is typical in empirical analyses of the causes of corruption, identifying such instruments is difficult since most candidate instruments have a potential direct influence on corruption. Consider one such example: Fiorina (1994) argues that the increasing prevalence of divided state governments can be attributed to the deterioration of Republican support in state legislatures. He explains this in turn partly by the increasing professionalization of the legislatures, in terms of full-time service and remuneration. This made legislative service relative more attractive to Democratic candidates, who are argued to have less lucrative outside career opportunities than Republican candidates.

We capture this effect by using as an instrument the average salary of state legislators in the 1980's. This is correlated with the occurrence of divided government in the 1990's (di Tella and Fisman 2004), but may also be correlated directly with corruption. ${ }^{14}$ The effect of salaries is insignificant and does not affect other results if included directly in the regressions of Tables 1 and

\footnotetext{
${ }^{14}$ For example, this would be the case if higher pay (legal rent-seeking) reduced the demand for corruption (illegal rentseeking).
} 
2. However, IV-analysis using other potential (weak) instrumental variables suggests that the inclusion of the salaries variable only in the first stage regression is inappropriate, as it results in a rejection of a test for no overidentification. Similar problems pertain to the instrumentation of judicial selection procedures. ${ }^{15}$ In sum, though, the fact that we were unable to identify appropriate instruments does not imply that the effect we identify is not causal. In fact, we are modestly confident that the observed correlation can be given a causal interpretation for the reasons given above.

\section{$\underline{\text { VI. Discussion and Concluding Remarks }}$}

We find that divided government in American states is associated with lower corruption. This confirms the popular perception of divided government as providing a system of checks and balances between the executive and legislative branches. The finding emphasizes the role of parties “on top” of institutions and, hence, provides, if indirectly, a qualification to Persson, Roland and Tabellini’s (1997) discussion of parliamentary vs. presidential regimes and their relationship with rent-seeking and corruption. Institutional separation of powers does not always imply a functional separation of powers if institutional actors can collude, something for which political parties provide a natural forum.

We also include the third branch of government, and find that having elected, rather than appointed, state supreme court judges is also associated with lower corruption and that divided government and elected supreme court judges are substitutes in curbing corruption. This means that the effect of a judiciary accountable to the public is stronger in states where the executive and legislative branches of government are controlled by the same party. These results accord with

\footnotetext{
${ }^{15}$ As noted above, there are very few changes in judicial selection procedures over the period covered by our sample. Further, selection procedures, and changes therein, in the 1990's are not correlated with convictions on corruption in the 1980's. Hence, concerns about bias related to judicial selection procedures should be concentrated on omitted variables such as "judicial culture," which may potentially be correlated with the selection procedures. In work on employment discrimination charges, Besley and Payne (2003) find no effects of instrumenting selection procedures.
} 
recent findings concerning the effects of the judiciary on outcomes (Besley and Payne, 2003), but may contradict a long-standing belief in the court reform literature (Hanssen, 2001; Hall, 2001) that appointed courts are more independent. ${ }^{16}$

Importantly, Besley and Payne (2003) observe that different notions of judicial independence are at work. On the one hand, there is independence from the executive and legislature, which is what is referred to as "independence" in both the court reform and comparative literatures (La Porta et al. 2004). This matters for the process of judicial review of laws affecting public policies. In the context of American state courts, judicial independence to some also implies independence from popular opinion (Baum, 2003). Appointed state supreme court judges are independent from popular opinion and may, as noted by La Porta et al. (2004) and Glaeser and Shleifer (2002) in a comparative context, therefore protect property rights to a larger extent.

However, at the state level such courts may not be independent from either big business and other interest groups or the executive branch of government due to the bundling of the political choice and judicial selection. This independence can be achieved by elected courts, though at the risk of judges pandering more to public opinion, which may or may not be desirable from a welfare point of view. ${ }^{17}$ Our results certainly are consistent with the view that accountability and independence from the legislative and executive branches are important for the judicial branch to provide a check on other branches of government so as to ensure that these do not abuse their public office for private gain. However, our results on the judiciary are only a first step towards an understanding of these mechanisms. Future research should concentrate on creating panels of corruption surveys in the US as well as better and more detailed data for effective checks and balances in comparative samples along the lines of La Porta et al. (2004).

\footnotetext{
${ }^{16}$ We examined whether the effect of appointed courts depends on party congruence or opposition. Appointed courts in opposition tend to have weakly higher corruption than courts with partisan congruence, with $p$-values around .2.

${ }^{17}$ See Brace and Boyea (2004) for an analysis of pandering by state supreme courts in the context of capital punishment.
} 


\section{Appendix: Data sources}

Variable

Corruption survey

Per cent metropolitan population

Real per capita income

Per cent with high school diploma

Real government revenue per capita

Initiatives

Term limits

Electoral competition

Primaries

Campaign spending restrictions

Per cent with Scandinavian ancestry

Divided government

Judicial selection procedures

Partisan measures of courts

Newspaper circulation
Source

Boylan and Long (2003)

Bureau of the Census

Statistical Abstract of the United States

Bureau of the Census

Statistical Abstract of the United States

Tolbert et al. (1999)

Besley and Case (2003) and http://www.termlimits.org

Holbrook and van Dunk (1993)

The Book of the States, various years

The Book of the States, various years

Bureau of the Census

The Book of the States, various years

The Book of the States, various years

Langer (2004)

Adserà et al. (2003) 


\section{$\underline{\text { References }}$}

Ades, Alberto and Rafael Di Tella. 1999. “Rents, Competition, and Corruption.” American Economic Review 89, 982-93.

Adserà, Alicia, Carles Boix, and Mark Payne. 2003. Journal of Law, Economics, and Organization 19, 445-490.

Alt, James E. and David Dreyer Lassen. 2003. “The Political Economy of Institutions and Corruption in American States.” Journal of Theoretical Politics 15, 341-365.

Barro, Robert J. 1973. “The Control of Politicians.” Public Choice 14, 19-42.

Baum, Lawrence. 2003. “Judicial Elections and Judicial Independence: The Voter's Perspective” Ohio State Law Journal 64(13).

Besley, Timothy. 2003. Principled Agents: Motivation and Incentives in Politics. Manuscript, LSE.

Besley, Timothy and Anne Case. 2003. "Political Institutions and Policy Choices: Evidence from the United States.” Journal of Economic Literature 41, 7-73.

Besley, Timothy and Stephen Coate. 2003. "Elected versus Appointed Regulators: Theory and Evidence.” Journal of the European Economic Association 1, 1176-1206.

Besley, Timothy and Abigail Payne. 2003. “Judicial Accountability and Economic Policy Outcomes: Evidence from Employment Discrimination Charges.” Manuscript, LSE and McMaster, October.

Boylan, Richard T. and Cheryl X. Long. 2003. "Measuring Public Corruption in the American States: A Survey of State House Reporters.” State Politics and Policy Quarterly 3, 420-38.

Brace, Paul and Brent Boyea. 2004. "State Supreme Court Decision-Making: A Re-Evaluation of the Electoral Connection.” Presented to the Annual Meeting of the American Political Science Association, Chicago, September.

Brace, Paul, Laura Langer and Melinda Gann Hall. 2000. “Measuring the Preferences of State Supreme Court Judges.” Journal of Politics 62, 387-413.

Di Tella, Rafael and Ray Fisman. 2004. “Are Politicians Really Paid Like Bureaucrats?” Journal of Law and Economics 47, 477-513.

Feld, Lars P. and Stefan Voigt. 2003. “Economic Growth and Judicial Independence: CrossCountry Evidence using a New Set of Indicators.” European Journal of Political Economy 19, 497-527.

Ferejohn, John. 1986. “Incumbent Performance and Electoral Control.” Public Choice 50, 5-26. 
Fiorina, Morris P. 1994. "Divided Government in the American States: A Byproduct of Legislative Professionalism?” American Political Science Review 88, 304-16.

Gerring, John and Strom C. Thacker. 2004. "Political Institutions and Corruption: The Role of Unitarism and Parliamentarism.” British Journal of Political Science 34, 295-330.

Glaeser, Edward and Claudia Goldin. 2004. “Corruption and Reform: An Introduction.” NBER Working Paper no. 10775, September.

Glaeser, Edward and Raven E. Saks. 2004. “Corruption in America.” NBER Working Paper no. 10821, September.

Glaeser, Edward and Andrei Shleifer. 2002. “Legal Origins.” Quarterly Journal of Economics 117, 1193-1229.

Hall, Melinda Gann. 2001. "State Supreme Courts in American Democracy: Probing the Myths of Judicial Reform.” American Political Science Review 95, 315-30.

Hall, Melinda Gann and Chris W. Bonneau. 2003. "Challengers, Margins, and State Supreme Court Elections.” Presented at APSA Annual Meeting, Philadelphia, September.

Hanssen, F. Andrew. 2001. "Independent Courts and Administrative Agencies: An Empirical Analysis of the States.” Journal of Law, Economics, and Organization 16, 534-71.

Hanssen, F. Andrew. 2004. “Is There a Politically Optimal Level of Judicial Independence?” American Economic Review 94, 712-729.

Holbrook, Thomas and Emily van Dunk. 1993. "Electoral Competition in the American States.” American Political Science Review 87, 955-962.

Knack, Stephen. 2002. "Social Capital and the Quality of Government: Evidence from the U.S. States.” American Journal of Political Science 46, 772-785.

Kunicová, Jana and Susan Rose-Ackerman. 2005. “Electoral Rules as Constraints on Corruption.” British Journal of Political Science 35, 573-606.

La Porta, Rafael, Florencio Lopez-de-Silanes, Christian Pop-Eleches and Andrei Shleifer. 2004. “Judicial Checks and Balances.” Journal of Political Economy 112, 445-470.

Laffont, Jean-Jacques. 2001. Incentives and Political Economy. Oxford University Press.

Langer, Laura. 2002. Judicial Review in State Supreme Courts. State University of NY Press. Langer, Laura. 2004. NSF CAREER Grant, SES-0092187 “Multiple Actors and Competing Risks in the Policymaking of Judicial Review.” University of Arizona, accessed June 2005.

Lassen, David Dreyer. 2005. “Ethnic Divisions, Trust, and the Size of the Informal Sector.” Journal of Economic Behavior and Organization, forthcoming. 
Maskin, Eric and Jean Tirole. 2004. “The Politician and the Judge.” American Economic Review 94, 1034-1054.

Maxwell, Amanda and Richard F. Winters. 2005. "Political Corruption in America.” Manuscript, Dartmouth College, May.

Meier Kenneth J. and Thomas M. Holbrook. 1992. “'I seen my opportunities and I took’em:

Political corruption in the American states.” Journal of Politics 54, 135-155.

Montinola, Gabriella and Richard Jackman. 2002. "Sources of Corruption: A Cross-Country Study.” British Journal of Political Science 32, 147-170.

Morgenstern, Albrecht. 2004. "Separation of Powers and Party Politics - On the Value of Divided

Government.” Presented to the Annual Meeting of the American Political Science

Association, Chicago, September.

Persson, Torsten, Gerard Roland and Guido Tabellini. 1997. "Separation of Powers and Political Accountability.” Quarterly Journal of Economics 112, 1163-1202.

Persson, Torsten, Gerard Roland and Guido Tabellini. 2000. “Comparative Politics and Public Finance.” Journal of Political Economy 108, 1121-1161.

Persson, Torsten and Guido Tabellini. 1999. “The Size and Scope of Government: Comparative Politics with Rational Politicians.” European Economic Review 43, 699-735.

Persson, Torsten, Guido Tabellini and Francesco Trebbi. 2003. "Electoral Rules and Corruption.” Journal of the European Economic Association 1, 958-989.

Salzberger, Eli M. 1993. “A Positive Analysis of the Doctrine of the Separation of Powers, or: Why Do We Have an Independent Judiciary?” International Review of Law and Economics 13, 349-379.

Schultz, Christian. 2005. “Information, Polarization and Delegation in Democracy.” Manuscript, University of Copenhagen.

Tolbert, Caroline J., Daniel H. Loewenstein and Todd Donovan. 1999. “Election Law and Rules for Using Initiatives,” in Bowler, Donovan and Tolbert (eds.): Citizens as Legislators: Direct Democracy in the United States, Ohio State University Press.

Treisman, Daniel. 2000. “The Causes of Corruption: A Cross-National Survey.” Journal of Public Economics 76, 399-457.

Wallis, John J. 2004. “The Concept of Systematic Corruption in American Political and Economic History.” Presented to NBER conference on Reform and Corruption, July. 
Table 1: Checks and Balances on Corruption in American states

\begin{tabular}{|c|c|c|c|c|c|c|}
\hline \multirow[b]{2}{*}{ Divided government measure } & \multicolumn{6}{|c|}{ Dependent variable: Corruption survey measure } \\
\hline & $\begin{array}{l}\text { DGOV } \\
\text { (1) }\end{array}$ & $\begin{array}{l}\text { DGOV } \\
\text { (2) }\end{array}$ & $\begin{array}{l}\text { DGOV } \\
\text { (3) }\end{array}$ & $\begin{array}{l}\text { DIVGOV } \\
\text { (4) }\end{array}$ & $\begin{array}{l}\text { DIVGOV } \\
\text { (5) }\end{array}$ & $\begin{array}{l}\text { DIVGOV } \\
(6)\end{array}$ \\
\hline Metropolitan population (in \%) & $\begin{array}{l}0.037^{\star \star \star} \\
(0.006)\end{array}$ & $\begin{array}{l}0.038^{\star \star \star} \\
(0.007)\end{array}$ & $\begin{array}{l}0.038^{* * *} \\
(0.006)\end{array}$ & $\begin{array}{l}0.039 \text { *** } \\
(0.005)\end{array}$ & $\begin{array}{l}0.039 \text { *** } \\
(0.005)\end{array}$ & $\begin{array}{l}0.036 \text { *** } \\
(0.005)\end{array}$ \\
\hline Real income per capita $(1000 \$)$ & $\begin{array}{l}-0.319 * \star \star \\
(0.106)\end{array}$ & $\begin{array}{l}-0.320 * * * \\
(0.111)\end{array}$ & $\begin{array}{l}-0.331 \text { *** } \\
(0.089)\end{array}$ & $\begin{array}{l}-0.296 \text { *** } \\
(0.087)\end{array}$ & $\begin{array}{l}-0.294 \text { *** } \\
(0.091)\end{array}$ & $\begin{array}{l}-0.298 \text { *** } \\
(0.084)\end{array}$ \\
\hline$\%$ of population with high school diploma & $\begin{array}{l}-0.057 \text { ** } \\
(0.024)\end{array}$ & $\begin{array}{l}-0.057 \\
(0.025)\end{array}$ & $\begin{array}{l}-0.053 \text { ** } \\
(0.023)\end{array}$ & $\begin{array}{l}-0.051 \text { ** } \\
(0.021)\end{array}$ & $\begin{array}{l}-0.049 \text { ** } \\
(0.022)\end{array}$ & $\begin{array}{l}-0.058 \text { *** } \\
(0.021)\end{array}$ \\
\hline General real tax revenue per capita $(1000 \$)$ & $\begin{array}{l}1.425 \text { *** } \\
(0.304)\end{array}$ & $\begin{array}{l}1.424 \\
(0.308)\end{array}$ & $\begin{array}{l}1.418^{* * *} \\
(0.295)\end{array}$ & $\begin{array}{l}1.613 * \star \star \\
(0.333)\end{array}$ & $\begin{array}{l}1.614 \\
(0.335)\end{array}$ & $\begin{array}{l}1.655 \text { *** } \\
(0.347)\end{array}$ \\
\hline$\%$ of population with Scand. ancestry & $\begin{array}{l}-0.040 * * * \\
(0.009)\end{array}$ & $\begin{array}{l}-0.040 * * * \\
(0.009)\end{array}$ & $\begin{array}{l}-0.043 \text { *** } \\
(0.008)\end{array}$ & $\begin{array}{l}-0.039 * * * \\
(0.006)\end{array}$ & $\begin{array}{l}-0.040 * * * \\
(0.006)\end{array}$ & $\begin{array}{l}-0.045 * * * \\
(0.007)\end{array}$ \\
\hline Divided government & $\begin{array}{l}-0.679 * \\
(0.371)\end{array}$ & $\begin{array}{l}-0.688 \text { * } \\
(0.392)\end{array}$ & $\begin{array}{l}-1.534 \text { *** } \\
(0.418)\end{array}$ & $\begin{array}{l}-0.8611^{\star \star \star} \\
(0.293)\end{array}$ & $\begin{array}{l}-0.858 \text { *** } \\
(0.296)\end{array}$ & $\begin{array}{l}-1.489 \text { *** } \\
(0.421)\end{array}$ \\
\hline Elected state supreme court judges & & $\begin{array}{r}-0.023 \\
(0.262)\end{array}$ & $\begin{array}{l}-0.506 \text { * } \\
(0.262)\end{array}$ & & $\begin{array}{r}-0.062 \\
(0.235)\end{array}$ & $\begin{array}{l}-0.691 \text { * } \\
(0.392)\end{array}$ \\
\hline Divided government*elected judges & & & $\begin{array}{l}1.610^{* * *} \\
(0.567)\end{array}$ & & & $\begin{array}{l}1.276 \text { ** } \\
(0.607)\end{array}$ \\
\hline $\mathrm{R}^{\wedge} 2$ & .68 & .68 & .72 & .70 & .70 & .73 \\
\hline No. of observations & 45 & 45 & 45 & 45 & 45 & 45 \\
\hline
\end{tabular}

Robust standard errors are reported in parentheses. A constant term was included in all regression but is not reported.

$\star * \star, * *$, and ${ }^{*}$ denote significance at the 99,95 and $90 \%$ levels, respectively.

All statistical work was carried out using STATA 8. 
Table 2: Checks, Balances, Politics, and Corruption

\begin{tabular}{|c|c|c|}
\hline Divided government measure & $\begin{array}{l}\text { DGOV } \\
\text { (3) }\end{array}$ & $\begin{array}{l}\text { DIVGOV } \\
(6)\end{array}$ \\
\hline$\overline{\text { Metropolitan population (in \%) }}$ & $\begin{array}{l}0.036 \text { *** } \\
(0.007)\end{array}$ & $\begin{array}{l}0.038^{\star \star \star} \\
(0.005)\end{array}$ \\
\hline Real income per capita $(1000 \$)$ & $\begin{array}{l}-0.334 \\
(0.088)\end{array}$ & $\begin{array}{l}-0.321 * * * \\
(0.081)\end{array}$ \\
\hline$\%$ of population with high school diploma & $\begin{array}{l}-0.047 * \\
(0.024)\end{array}$ & $\begin{array}{l}-0.046 * * \\
(0.021)\end{array}$ \\
\hline General real tax revenue per capita $(1000 \$)$ & $\begin{array}{l}1.346 \text { *** } \\
(0.302)\end{array}$ & $\begin{array}{l}1.749 * * \star \\
(0.350)\end{array}$ \\
\hline$\%$ of population with Scand. ancestry & $\begin{array}{l}-0.047^{* * *} \\
(0.009)\end{array}$ & $\begin{array}{l}-0.048 * * * \\
(0.007)\end{array}$ \\
\hline Divided government & $\begin{array}{l}-1.554 * \star \star \\
(0.446)\end{array}$ & $\begin{array}{l}-1.494 \\
(0.436)\end{array}$ \\
\hline $\begin{array}{l}\text { Elected state supreme court judges } \\
\text { from governor's party }\end{array}$ & $\begin{array}{l}-0.370 \\
(0.271)\end{array}$ & $\begin{array}{r}-0.500 \\
(0.387)\end{array}$ \\
\hline $\begin{array}{l}\text { Elected state supreme court judges } \\
\text { in opposition to governor's party }\end{array}$ & $\begin{array}{l}-0.748 \\
(0.451)\end{array}$ & $\begin{array}{l}-2.555 \\
(1.211)\end{array}$ \\
\hline Divided government*elected judges, governor's party & $\begin{array}{r}0.632 \\
(0.945)\end{array}$ & $\begin{array}{r}0.855 \\
(0.638)\end{array}$ \\
\hline Divided government*elected judges, opposition party & $\begin{array}{l}2.264 \\
(0.766)\end{array}$ & $\begin{array}{l}3.982 * * \\
(1.648)\end{array}$ \\
\hline$\overline{R^{\wedge} 2}$ & .74 & .75 \\
\hline No. of observations & 45 & 45 \\
\hline
\end{tabular}

Robust standard errors are reported in parentheses. A constant term was included in all regression but is not reported. ***, **, and * denote significance at the 99,95 and $90 \%$ levels, respectively.

All statistical work was carried out using STATA 8. 
Table 3: Checks and Balances including additional controls

\begin{tabular}{|c|c|c|c|c|c|}
\hline \multirow[b]{2}{*}{ Divided government measure } & \multicolumn{5}{|c|}{ Dependent variable: Corruption survey measure } \\
\hline & $\begin{array}{c}\text { DIVGOV } \\
(7)\end{array}$ & $\begin{array}{c}\text { DIVGOV } \\
\text { (8) }\end{array}$ & $\begin{array}{c}\text { DIVGOV } \\
\text { (9) }\end{array}$ & $\begin{array}{c}\text { DIVGOV } \\
\text { (10) }\end{array}$ & $\begin{array}{c}\text { DIVGOV } \\
\text { (11) }\end{array}$ \\
\hline Metropolitan population (in \%) & $\begin{array}{l}0.037^{\star \star \star} \\
(0.005)\end{array}$ & $\begin{array}{l}0.036 \text { *** } \\
(0.005)\end{array}$ & $\begin{array}{l}0.037^{\text {** }} \\
(0.006)\end{array}$ & $0^{0.036}{ }^{\star \star \star *}$ & $\begin{array}{l}0.035 \\
(0.006)\end{array}$ \\
\hline Real income per capita $(1000 \$)$ & $\begin{array}{l}-0.300 \\
(0.073)\end{array}$ & $\begin{array}{l}-0.263 \text { *** } \\
(0.082)\end{array}$ & $\begin{array}{l}-0.289 \\
(0.107)\end{array}$ & $\begin{array}{l}-0.310 \\
(0.086)\end{array}$ & $\begin{array}{l}-0.288 \text { *** } \\
(0.088)\end{array}$ \\
\hline$\%$ of population with high school diploma & $\begin{array}{l}-0.103 \\
(0.030)\end{array}$ & $\begin{array}{l}-0.073^{* * *} \\
(0.021)\end{array}$ & $\begin{array}{l}-0.061 \text { * } \\
(0.031)\end{array}$ & $\begin{array}{l}-0.066 \text { *** } \\
(0.021)\end{array}$ & $\begin{array}{l}-0.058 \text { *** } \\
(0.021)\end{array}$ \\
\hline General real tax revenue per capita $(1000 \$)$ & $\begin{array}{l}1.510 \\
(0.308)\end{array}$ & $\begin{array}{l}1.522 \\
(0.337)\end{array}$ & $\begin{array}{l}1.693 \text { *** } \\
(0.435)\end{array}$ & $\begin{array}{l}1.624 \\
(0.341)\end{array}$ & $\begin{array}{l}1.649 \text { *** } \\
(0.346)\end{array}$ \\
\hline$\%$ of population with Scand. ancestry & $\begin{array}{l}-0.046 \\
(0.008)\end{array}$ & $\begin{array}{l}-0.039 \\
(0.009)\end{array}$ & $\begin{array}{l}-0.041 \text { *** } \\
(0.010)\end{array}$ & $\begin{array}{l}-0.047 \\
(0.008)\end{array}$ & $\begin{array}{l}-0.044 \\
(0.007)\end{array}$ \\
\hline Divided government & $\begin{array}{l}-1.714 \\
(0.355)\end{array}$ & $\begin{array}{l}-1.479 \\
(0.427)\end{array}$ & $\begin{array}{l}-1.442 \\
(0.464)\end{array}$ & $\begin{array}{l}-1.551 \\
(0.407)\end{array}$ & $\begin{array}{l}-1.451 \\
(0.441)\end{array}$ \\
\hline Elected state supreme court judges & $\begin{array}{l}-0.801 \text { ** } \\
(0.377)\end{array}$ & $\begin{array}{l}-0.671 \text { * } \\
(0.385)\end{array}$ & $\begin{array}{r}-0.663 \\
(0.395)\end{array}$ & $\begin{array}{l}-0.745 \text { * } \\
(0.373)\end{array}$ & $\begin{array}{r}-0.674 \\
(0.409)\end{array}$ \\
\hline Divided government*elected judges & $\begin{array}{l}1.324 \text { ** } \\
(0.580)\end{array}$ & $\begin{array}{l}1.336 \\
(0.636)\end{array}$ & $\begin{array}{l}1.244 \text { * } \\
(0.631)\end{array}$ & $\begin{array}{l}1.311 \text { ** } \\
(0.581)\end{array}$ & $\begin{array}{l}1.243 \text { * } \\
(0.617)\end{array}$ \\
\hline Southern state & $\begin{array}{l}-0.736 \\
(0.361)\end{array}$ & & & & \\
\hline Campaign expenditure restrictions & & $\begin{array}{l}-0.569 \text { *** } \\
(0.205)\end{array}$ & & & \\
\hline Open primaries & & $\begin{array}{r}-0.242 \\
(0.242)\end{array}$ & & & \\
\hline Term limits & & & $\begin{array}{r}0.152 \\
(0.275)\end{array}$ & & \\
\hline Initiatives & & & $\begin{array}{r}-0.057 \\
(0.505)\end{array}$ & & \\
\hline Initiatives*required threshold & & & $\begin{array}{r}0.017 \\
(0.059)\end{array}$ & & \\
\hline Politcal competition & & & & $\begin{array}{r}0.008 \\
(0.012)\end{array}$ & \\
\hline Newspapers per capita & & & & & $\begin{array}{r}-0.836 \\
(2.086) \\
\end{array}$ \\
\hline$\overline{R^{\wedge} 2}$ & .76 & .77 & .73 & .73 & .73 \\
\hline No. of observations & 45 & 45 & 45 & 45 & 45 \\
\hline
\end{tabular}

Robust standard errors are reported in parentheses. A constant term was included in all regression but is not reported. $\star \star \star, ~ * \star$, and * denote significance at the 99,95 and $90 \%$ levels, respectively.

All statistical work was carried out using STATA 8. 